\title{
DRYING CHARACTERISTICS OF OKRA BY DIFFERENT SOLAR DRYERS
}

\author{
Mohamed M. A*., G. R. Gamea**,
}

\section{H. Keshek***}

\begin{abstract}
Drying of agricultural products is the great importance for preservation of food by human beings. Solar drying refers to a technique that utilizes incident solar radiation to convert it into thermal heat energy for drying purposes. The drying operation is mainly affected by variation of the air drying temperature, air flow rate and air relative humidity. The research was carried out to study the drying characteristics of okra to achieve highly drying rates and good quality. Three similar drying units were designed and manufactured in the Faculty of Agricultural., Menoufiya University and installed on the roof of Agricultural Engineering building. Each unit consists of solar collector, drying chamber, drying trays, chimney, and suction fan. Drying characteristics of okra treated by 1.0\% sodium carbonates at boiling point for three minuets under different drying systems and flow rates of air $0.075 \mathrm{~m}^{3} / \mathrm{sec}, 0.149 \mathrm{~m}^{3} / \mathrm{sec}$, and $0.249 \mathrm{~m}^{3} / \mathrm{sec}$ at the same time. Computer program used to define the fit mathematical model described the dying curves of okra in different conditions. The obtained results showed that, indirect dryer for drying okra at air flow rate of $0.075 \mathrm{~m}^{3} / \mathrm{sec}$ achieved the best quality. The drying efficiency was decreased as, the moisture content of okra crop reduced.
\end{abstract}

\section{INTRODUCTION}

The drying process is a heat and mass transfer phenomenon where
water migrates from the interior of the drying product on the
surface from which it evaporates. Basically, the microorganisms that destroy food require moisture to live. In addition to preservation, dehydration reduces product weight and volume by significant amounts and improves the efficiency of product transportation and storage.

\footnotetext{
* Prof. and Head of Agric. Eng. Dept., Fac. of Agric., Minoufiya Univ. ** Assoc. Prof., Agric. Eng. Dept., Fac. Of Agric., Minoufiya Univ. *** Assistant Lecturer, Agric. Eng. Dept, Fac. Of Agric., Minoufiya Univ. Agric. Eng., Fac. Of Agric., Minoufiya Univ., Shiben El Kom, Egypt.
} 
The use of solar driers helps to eliminate the air pollution problems caused by fossil fuel dryers. The conditions in the tropical countries make the use of solar energy for drying food particularly attractive. Egypt is one of the countries which have favorable solar energy condition. It has a clear sky almost all the year around except few days during winter and spring seasons. The utilization of solar energy for drying fruits and vegetables can contribute a significant agro-industrial development.

Solar drying systems must be properly designed in order to meet particular drying requirements of specific crops and give satisfactory performance with respect to energy requirement (Steinfield and Segal., 1986)

Okra probably originates is east African, quite possibly in Ethiopia. It is widely grown in all the regions of the world with a tropical or Mediterranean climate for its immature pods. It grows best in hot weather (temperatures above $26{ }^{\circ} \mathrm{C}$ ). Nowadays, the most important okraproducing countries are India, Nigeria, Pakistan, Ghana and Egypt (FAO, 2003).

Okra is traditionally preserved by drying on various surfaces such as the ground, racks, trays and concrete floors. Although sun drying is the most common method used to preserve agricultural products in tropical and sub-tropical countries, this technique is extremely weather dependent, and has the problem of contamination with foreign matter. Also, the required drying time can be quite long and the sensory qualities of the final product can deteriorate. Therefore, an effective means of overcoming these problems is to dry the okra and other vegetables with solar and hot-air dryers (Ibrahim, 2005). A review of the various methods of okra drying currently available will be presented.

El- Shiatry et al., (1992) tested a solar tunnel drier for drying okra with capacity of 100-200 kg/day. An organoleptic evaluation gave results between good and excellent for all dried pods. The reconstitution properties of the dried samples were sufficient.

El- Yateem (1995) reported that the end point of the drying process of okra could be determined when the okra pods were brittle as it berates readily upon slight pressure. 
Combined effect of drying time and slice thickness on the solar drying of okra was studied by Adom et al., (1997). They concluded that it is evident from the overall results that, the solar drying is an effective method for producing dried okra, which allows for shorter drying periods compared with the traditional open-air sun drying method. However, the drying time the slice thickness and the combined effect of these two parameters are very important factors to consider in producing the dried okra. From this study, a slice thickness of $10.0 \mathrm{~mm}$ and drying time $48 \mathrm{~h}$ would be most suitable for the solar drying of okra using a solar tent dryer.

Several mathematical modeling and experimental studies have been conducted on the thin layer solar drying processes of various vegetables and fruits, such as grapes (Yaldiz et al., 2001), apricots (Togrul and Pehlivan., 2002), green pepper, green bean and squash (Yaldiz and Ertekin., 2001), pistachio (Midilli and Kucuk., 2003), red pepper (Ebru et al., 2003), and prickly pear fruit (Lahsasni et al., 2004).

Many attempts have been made to develop and enhance the drying behavior of the thin layer drying for some agricultural products, however some of results achieved with these dryers have not been satisfactory.

Therefore the present research was conducted to study the following points:

1- Effect of air flow rate on drying characteristics of okra.

2- Effect of different solar drying driers on drying characteristics of product and its quality.

3- Fitting the mathematical models which describe the thin layer solar drying curves of the product.

\section{MATERIALS AND METHODS}

\section{Equipment}

Three identical drying systems were designed and manufactured in the Faculty of Agricultural., Menoufiya University and installed on the roof of Agricultural Engineering Buillding as shown in Fig.(1).The main components of each drying system are:-

\section{1- Solar collector (air heater)}

The solar collector was made of wooden box having a gross dimensions 
of $1.0 \mathrm{~m}$ long, $0.75 \mathrm{~m}$ wide and $0.20 \mathrm{~m}$ deep. The walls and bottom was constructed of two layer of plywood ( $3 \mathrm{~mm}$ thick) and the space between the two layer are insulated by foam layer ( $0.03 \mathrm{~m}$ thick), this box painted from inside and outside by a blackboard paint mixed with $50 \%$ by weight of a talc powder i.e. (too fin zinc oxide, nontraditional paint) according to (Ghanem., 2003). The absorber plate is formed from a corrugated iron sheets which is a good conductor of heat. It is painted with matt black paint (Ghanem., 2003) in order to absorber the maximum amount of the solar radiation. The gross dimensions of the absorber plate are $1.0 \mathrm{~m}$ long, $0.62 \mathrm{~m}$ wide, and $0.5 \mathrm{~mm}$ thick with a net surface area of $0.62 \mathrm{~m}^{2}$. The solar collector was covered with one layer of a clear glass, $3 \mathrm{~mm}$ thick to reduce the reflection of radiation and heat losses by convection. The solar collector was attached with the drying chamber by an air duct. The air duct having across section area of $\left(0.14 \mathrm{~m}^{2}\right)$. The solar collector was oriented to face the south direction and tilted with an optimum tilt angle at noon.

\section{2- Drying chamber}

The side walls and bottom of drying chamber are constructed of two layers of plywood ( $3 \mathrm{~mm}$ thick) and the space between the two layers are insulated by foam layer ( $3 \mathrm{~cm}$ thick). The drying chamber is constructed with shelves which are arranged in a stepped pyramidal face to expose products in all trays on the shelves to direct sunlight as shown in Fig.(1). The chamber door was located in the back side of the chamber and made from the same material of the walls with $0.70 \mathrm{~m}$ long and $0.5 \mathrm{~m}$ wide. The drying chamber was mounted to face the south direction and covered with glass ( $3 \mathrm{~mm}$ thick) with a net surface area of $\left(0.788 \mathrm{~m}^{2}\right)$ and tilted at an angle of $30^{\circ}$ which is the optimum slope angle at noon. Drying air inters the chamber after leaving the solar collector through a hole with area of $\left(0.14 \mathrm{~m}^{2}\right)$ and passing through the trays from the top to the bottom as shown in Fig.(1).The stepped pyramidal face of the drying chamber provides with two shelves for positioning the drying trays.

\section{3- Drying trays}

The drying chamber was equipped by two drying trays which made of wooden frame $(0.35 \mathrm{~m} \times 0.65 \mathrm{~m})$ and stainless steel screen mesh in the bottom. 


\section{4- Chimney}

To provide the draft needed to amplify the natural convection currents to displace the humid air in the cabinet, a cylindrical chimney with an internal diameter of $0.25 \mathrm{~m}$ and $0.5 \mathrm{~m}$ high, was installed over the exit air opening on the top of the cabinet.

5-Extracting fan An extracting fan of $0.25 \mathrm{~m}$ diameter (Sonya, mode 20wuc) 220-240 volts (50 Hertz) made in Egypt was functioned in the experimental work.

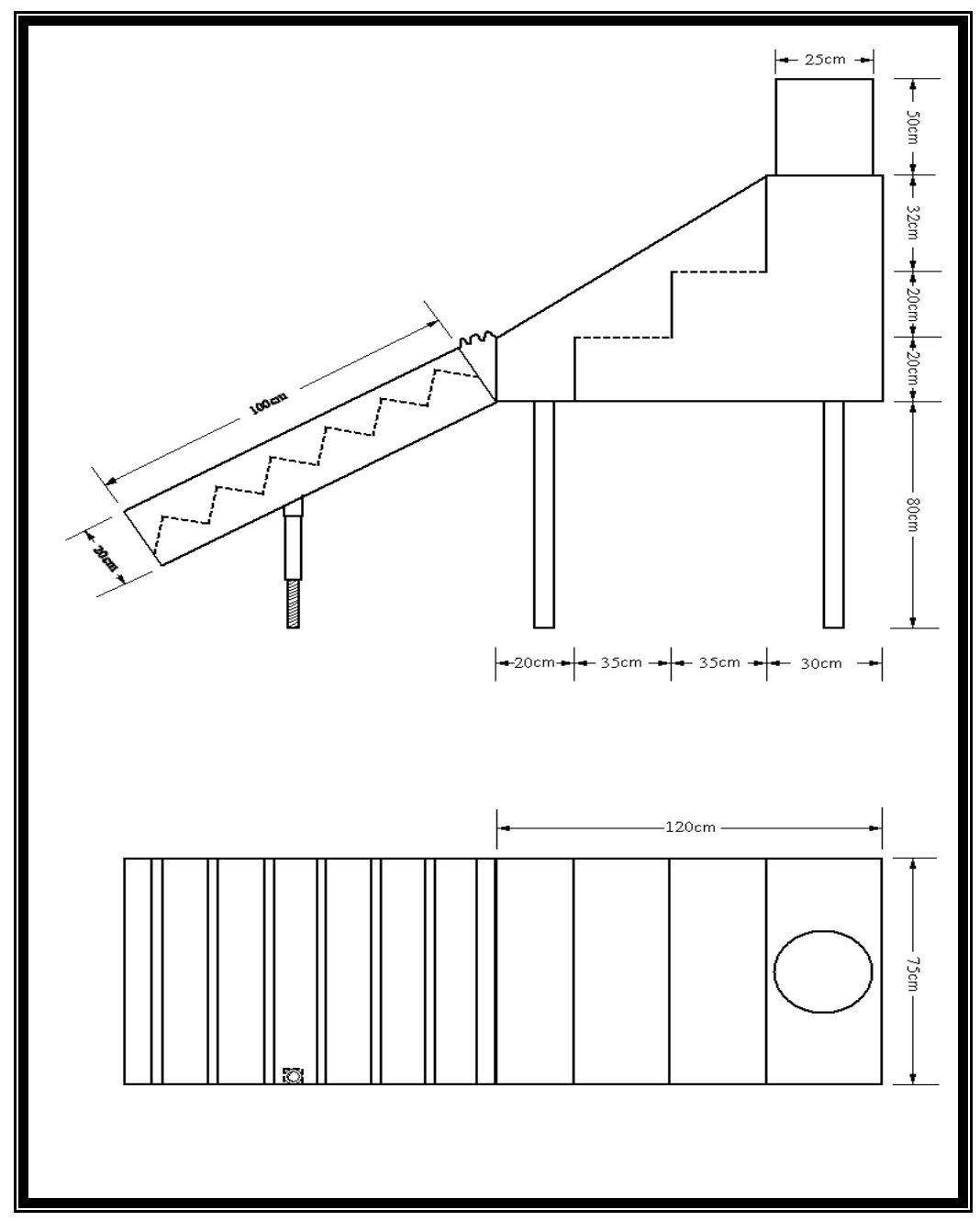

Fig. (1): Schematic diagram of solar drying system (Dim. In cm) 


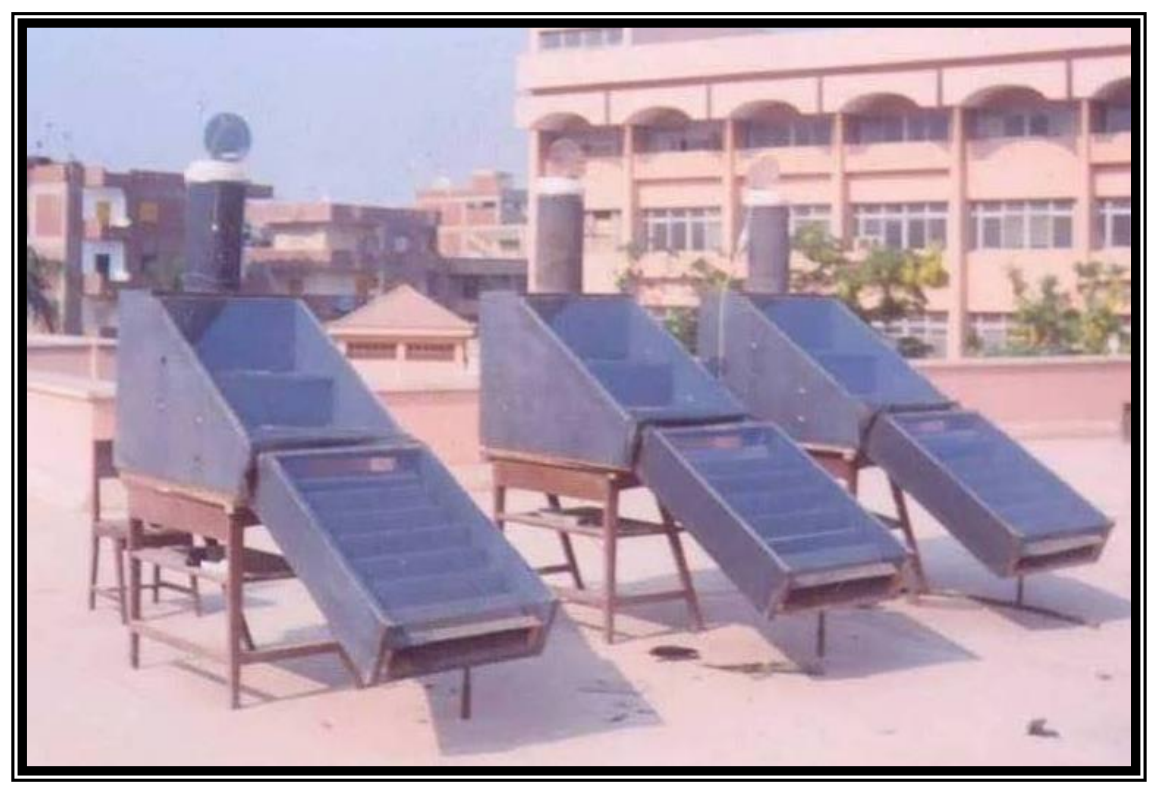

Fig. (2 )Solar drying systems.

\section{Measurements.}

\section{Solar Radiation}

The LI200X pyranometer was used to measure the solar radiation flux incident with silicon Photovoltaic detector mounted in cosine-corrected head. Solar radiation was measured by wiring the LI200X to Datalogger analog inputs with instruction Differential voltage (P2). Solar radiation recorded daily with flux intensity in $\mathrm{MJ} / \mathrm{m}^{2}$. The output from the LI200X was $0.2 \mathrm{KW} / \mathrm{m}^{2} / \mathrm{mV}$. Multiplier and offset were 0.002 for $10 \mathrm{sec}$ interval to convert the output from $\mathrm{KW} / \mathrm{m}^{2} / \mathrm{mV}$ unit into daily total flux intensity with $\mathrm{MJ} / \mathrm{m}^{2}$ unit.

\section{Temperature and relative humidity}

The temperature $\left({ }^{\circ} \mathrm{C}\right)$ and air relative humidity $(\%)$ were measured using a Rotronic Instruments UK ltd.

Technical data of it were:

-Humidity sensor: Hygrometer Ck90 Temperature: Silicon diode;

-Measuring range: humidity $(0-100 \% \mathrm{RH})$, temperature $\left(-10-+60^{\circ} \mathrm{C}\right)$;

-Accuracy at $25^{\circ} \mathrm{C}$ : humidity $\pm 2 \% \mathrm{RH}$, temperature $\pm 0.3^{\circ} \mathrm{C}$.

The measurements at a certain time intervals ( 2 hours) were recorded. The temperature and air relative humidity were measured in the required measuring points (ambient temperature, outlet air of collector, and inside 
the drying chamber to measure the air temperature at three different locations up and under the tray and at outlet of drying chamber).

Air speed: The air speed of drying air, inside the dryer and inside the collector was measured using a DWYER THERMAL ANEMOMETER 470 to the nearest $\mathrm{ft} / \mathrm{min}$. The readings were then converted into $\mathrm{m} / \mathrm{min}$.

Weight: Initial and final weights and weight changes during drying process of each sample were measured by a laboratory electric balance having accuracy of $0.01 \mathrm{gm}$

Moisture content: The moisture content of the products was determined according to Awady et al., (1988) by drying the products in an electrical oven at $70^{\circ} \mathrm{C}$ for 24 hours. The quantity of moisture present in a material can be expressed either on the wet basis or dry basis and expressed either as decimal or percentage.

\section{Materials}

Okra local variety was obtained from private farm in Elbagor, Minoufiya, Egypt, harvested by hand and transported immediately to the laboratory on the same day. The average diameter, length, and weight of the samples were $1.4 \mathrm{~cm}, 3.78 \mathrm{~cm}$ and $4.1 \mathrm{~g}$, respectively. The samples were dried by three different methods; in all methods the whole okra was pretreated by ( $1 \%$ sodium carbonates at boiling for three minutes according to (Saad et al., 1992). Some samples were picked randomly from the pretreated okra to determine the initial moisture content. The pretreated okra was spread on the mesh trays of the drying chambers. The drying trays were loaded by five kilograms per square meter.

\section{Methods}

\section{Solar drying characteristics of okra using forced direct solar driers}

The main goal of this experiment was to study the effect of air flow rate on the drying behavior of products and drying rate. Three different flow rates of drying air were used. The air flow rate in the first, second, and third drying chambers were respectively, $0.075,0.149$, and $0.249 \mathrm{~m}^{3} / \mathrm{sec}$.

Solar drying characteristics of okra using three different solar drying systems

The main objective of this experiment was to investigate the effect of drying systems on drying characteristics of products and the quality of dried products. The treated products were spread on the mesh trays of the 
three drying chambers. In the first drying chamber were used the air flow rate of $0.075 \mathrm{~m}^{3} / \mathrm{sec}$ and the drying chamber was covered by black plastic sheet to reduce the direct solar radiation flux incident on the drying system. The second drying chamber were used the same air flow rate that employed in the first chamber and leaved as it to make it a direct solar drying system by forced air. Finally the third drying chamber was leaved to the direct solar radiation drying system with natural air convection.

The drying tests were terminated when the decrease in the weight of the samples had almost ceased. The dried samples were weighed and values were used to determine the final moisture content. Solar drying experiments were carried out during Aug. 2006.

\section{Evaluation of solar drying}

\section{Driers efficiency}

The drying efficiency $\eta_{D}$ is the ratio of the energy required to evaporate the moisture from the crop to the insulation received over the area of drying chamber and energy received from solar collector, given as:-

$$
\eta_{D}=\frac{W_{r} L_{v}}{\left(I A+Q_{c}\right) t} \times 100 \quad, \%
$$

Where :-

$\eta_{\mathrm{D}} \quad=$ drying efficiency,$\%$

$\mathrm{W}_{\mathrm{r}} \quad=$ moisture removal, $\mathrm{kg}$

$\mathrm{L}_{\mathrm{v}} \quad=$ latent heat of vaporization, $\mathrm{J} / \mathrm{kg}$

I = solar intensity on horizontal surface, $\mathrm{W} / \mathrm{m}^{2}$

A $\quad=$ surface area of drying chamber, $\mathrm{m}^{2}$

$\mathrm{t} \quad=$ desired time period, $\mathrm{s}$

$\mathrm{Q}_{\mathrm{c}} \quad=$ useful heat gain to drying process.

$\mathrm{Q}_{\mathrm{c}} \quad=\mathrm{mC}_{\mathrm{P}}\left(\mathrm{T}_{\mathrm{o}}-\mathrm{T}_{\mathrm{i}}\right)$,Watt

Where:-

$$
\begin{array}{ll}
\mathrm{m} & =\text { mass flow rate of air, } \mathrm{kg} / \mathrm{s} \\
\mathrm{C}_{\mathrm{p}} & =\text { specific heat of air }=1007, \mathrm{~J} / \mathrm{kg} .{ }^{\circ} \mathrm{K} \\
\mathrm{T}_{\mathrm{o}} & =\text { outlet air temperature, }{ }^{\circ} \mathrm{K} \\
\mathrm{T}_{\mathrm{i}} & =\text { inlet air temperature, }{ }^{\circ} \mathrm{K}
\end{array}
$$




\section{Modeling the drying characteristics}

The solar drying curves were fitted with eleven different moisture ratio equations given by several researchers as listed in Table 1 . To calculate the coefficients of each model and select the best model for describing the drying curves, the nonlinear optimization method was applied, using the computer programs (Curve Expert 3.1, 1996 and Datafit 8.0 ,2002).

\begin{tabular}{|c|c|c|}
\hline \multicolumn{3}{|c|}{$\begin{array}{l}\text { Table 1: Mathematical models applied to the drying curves, } \\
\text { (Mohamed et al., 2005). }\end{array}$} \\
\hline $\begin{array}{l}\text { Model } \\
\text { number }\end{array}$ & Model name & Model expression \\
\hline 1 & Newton & $\mathrm{MR}=\mathrm{e}^{(-\mathrm{k} . \mathrm{t})}$ \\
\hline 2 & Page & $\mathrm{MR}=e^{\left(-k \cdot t^{n}\right)}$ \\
\hline 3 & Henderson and Pabis & $\mathrm{MR}=\mathrm{a} \cdot \mathrm{e}^{(-\mathrm{k} \cdot \mathrm{t})}$ \\
\hline 4 & Logarithmic & $\mathrm{MR}=\mathrm{a} \cdot \mathrm{e}^{(-\mathrm{k} \cdot \mathrm{t})}+\mathrm{c}$ \\
\hline 5 & Two term & $\mathrm{MR}=\mathrm{a} \cdot e^{\left(-k_{0} \cdot t\right)}+\mathrm{b} e^{\left(-k_{1} \cdot t\right)}$ \\
\hline 6 & Two term exponential & $\mathrm{MR}=\mathrm{a} \cdot \mathrm{e}^{(-\mathrm{k} \cdot \mathrm{t})}+(1-\mathrm{a}) \mathrm{e}^{(-\mathrm{k} \cdot \mathrm{a} \cdot \mathrm{t})}$ \\
\hline 7 & Wang and Singh & $\mathrm{MR}=1+\mathrm{a} \cdot \mathrm{t}+\mathrm{bt}^{2}$ \\
\hline 8 & Approximation of diffusion & $\mathrm{MR}=\mathrm{a} \mathrm{e}^{(-\mathrm{k} \cdot \mathrm{t})}+(1-\mathrm{a}) \mathrm{e}^{(-\mathrm{k} \cdot \mathrm{b} \cdot \mathrm{t})}$ \\
\hline 9 & Modified Henderson and Pabis & $\mathrm{MR}=\mathrm{a} \mathrm{e}^{(-\mathrm{k} \cdot \mathrm{t})}+\mathrm{b} \cdot \mathrm{e}^{(-\mathrm{g} \cdot \mathrm{t})}+\mathrm{c} \cdot \mathrm{e}^{(-\mathrm{h} . \mathrm{t})}$ \\
\hline 10 & Verma et al. & $M R=a e^{(-k \cdot t)}+(1-a) e^{(-g . t)}$ \\
\hline 11 & Midilli-Kucuk & $\mathrm{MR}=\mathrm{a} e^{\left(-k \cdot t^{n}\right)}+\mathrm{b} . \mathrm{t}$ \\
\hline
\end{tabular}

\section{Evaluation of dried okra}

The quality of dried okra was measured by testing final moisture content, rehydration ratio, bulk density and color.

Rehydration ratio was measured as the total mass of rehydrated product per unit dry matter after rehydration. Rehydration values were calculated after boiling $10 \mathrm{~g}$ dried okra in $300 \mathrm{ml}$ distilled water for $30 \mathrm{~min}$.

Bulk density was measured as the weight per unit volume of the cylinder which contained the dried product. A $100 \mathrm{ml}$ graduated cylinder was used and the weight needed to fill the cylinder to $500 \mathrm{ml}$ mark was measured, then the bulk density was determined. 
Color can be evaluated by determine chlorophylls (A and B) according to El-Yateem, (1995), five grams of the homogenized vegetable were mixed with $30 \mathrm{ml}$ of $85 \%$ acetone in dark bottle and then left to stand for 15 hours at room temperature. The samples were then filtered on glass wool into a $100 \mathrm{ml}$ volumetric flask, and reached to the volume by adding $85 \%$ acetone solution. The optical density of the sample was then measured in shemadzo spectrophotometer at 644 and $662 \mathrm{~nm}$. Acetone $(85 \%)$ was used at blank each measurements.

The contents of total chlorophylls were calculated using the following equations:

chlorophyll $\mathrm{A}=(9.78 \times \mathrm{E} 644)-(0.99 \times \mathrm{E} 644) \quad, \mathrm{mg} / \mathrm{liter}$

chlorophyll B $=(21.426 \times \mathrm{E} 644)-(4.65 \times \mathrm{E} 662) \quad, \mathrm{mg} / \mathrm{liter}$

where :-

$\mathrm{E}=$ sample optical density at the indicated wave length.

\section{RESULTS AND DISCUSSION}

During the drying experiments, the amount of solar radiation ranged from 788.8 to $908.3 \mathrm{~W} / \mathrm{m}^{2}$ at noon on the horizontal plane. Ambient air temperature ranged from 33.7 to $37.7{ }^{\circ} \mathrm{C}$ at noon, air relative humidity ranged between 24.6 to $35.7 \%$ at noon, the air temperature and solar radiation were always relatively low at the beginning and end of each day while reached the maximum values at noon.

Drying air temperature of okra by natural convection direct solar dryers reached the maximum values ranged between 53.9 to $55.4^{\circ} \mathrm{C}$ at noon. While the relative humidity of drying air were ranged between 3.6 to $5 \%$ at noon. The values of air drying temperature of okra by forced convection direct solar dryers with air flow rate of $0.075 \mathrm{~m}^{3} / \mathrm{sec}$ was higher than that with air flow rates of $0.149 \mathrm{~m}^{3} / \mathrm{sec}$ and $0.249 \mathrm{~m}^{3} / \mathrm{sec}$.

The maximum values of air drying temperature were $55.7,48.6,39.7{ }^{\circ} \mathrm{C}$ with air flow rates of $0.075,0.149$ and $0.249 \mathrm{~m}^{3} / \mathrm{sec}$, respectively. The minimum relative humidity of air drying was $6.3,7.5$, and $15.2 \%$ with air flow rates of $0.075,0.149$ and $0.249 \mathrm{~m}^{3} / \mathrm{sec}$, respectively.

The maximum values of air drying temperature were 60.6, 62.2 and 52.1 ${ }^{\circ} \mathrm{C}$ in the forced convection direct solar dryer, natural convection direct solar dryer, and forced convection indirect solar dryer, respectively, with 
air flow rate of $0.075 \mathrm{~m}^{3} / \mathrm{sec}$. While the minimum values of air relative humidity were $3.1,5.7$ and $6.5 \%$ in the forced convection direct solar dryer, natural convection direct solar dryer, and forced convection indirect solar dryer, respectively, with air flow rate of $0.075 \mathrm{~m}^{3} / \mathrm{sec}$.

\section{Solar drying curves of okra.}

Fig.(2) shows the moisture content versus drying time (drying curves) for okra dried by forced convection solar dryer with different flow rates. The drying time for reducing initial moisture content of pretreated okra was $792.86 \%$ (d.b) to the final moisture content of $10.41 \%$ (d.b) in the forced convection direct solar dryer with air flow rate of $0.075 \mathrm{~m}^{3} / \mathrm{sec}$ was16 hours. Meanwhile, the drying time to reach the final moisture content of $10.69 \%$ (d.b) with air flow rate of $0.149 \mathrm{~m}^{3} / \mathrm{sec}$ was 22 hours. Whereas, the drying time to reach the final moisture content of $10.84 \%$ (d.b) with air flow rate of $0.249 \mathrm{~m}^{3} / \mathrm{sec}$ was 32 hours. Consequently, the shortest drying time 16 hours was achieved with the lowest air flow rate of $0.075 \mathrm{~m}^{3} / \mathrm{sec}$. The maximum drying rate of pretreated okra in the forced convection direct solar driers taken between 2 to 4 hours with air flow rate of $0.075 \mathrm{~m}^{3} / \mathrm{sec}$, meanwhile, it occurred between 2 to 6 hours with air flow rate of $0.149 \mathrm{~m}^{3} / \mathrm{sec}$ and occurred between 2 to 10 hours at air flow rate of $0.249 \mathrm{~m}^{3} / \mathrm{sec}$.

Fig.(3) shows the relationship between the moisture content \% (d.b) and the drying rate $(\mathrm{gw} / \mathrm{gdm} . \mathrm{hr})$ for pretreated okra in forced convection direct solar driers with different flow rates of air. It revealed that the short constant rate period which lasted down to a critical moisture contents of about $28.79 \%$ (d.b), $38.39 \%$ (d.b), and $80.61 \%$ (d.b) were accomplished with air flow rates of $0.075 \mathrm{~m}^{3} / \mathrm{sec}, 0.149 \mathrm{~m}^{3} / \mathrm{sec}$ and $0.249 \mathrm{~m}^{3} / \mathrm{sec}$, respectively, and exhibited approximately linear falling rate period.

Fig. (4) shows the moisture content versus drying time (drying curves) for okra dried by different solar drying systems. The drying time for reducing initial moisture content of pretreated okra was $792.86 \%$ (d.b) to the final moisture content of $10.47 \%$ (d.b) in the forced convection direct solar dryer with air flow rate of $0.075 \mathrm{~m}^{3} / \mathrm{sec}$ was 18 hours. 


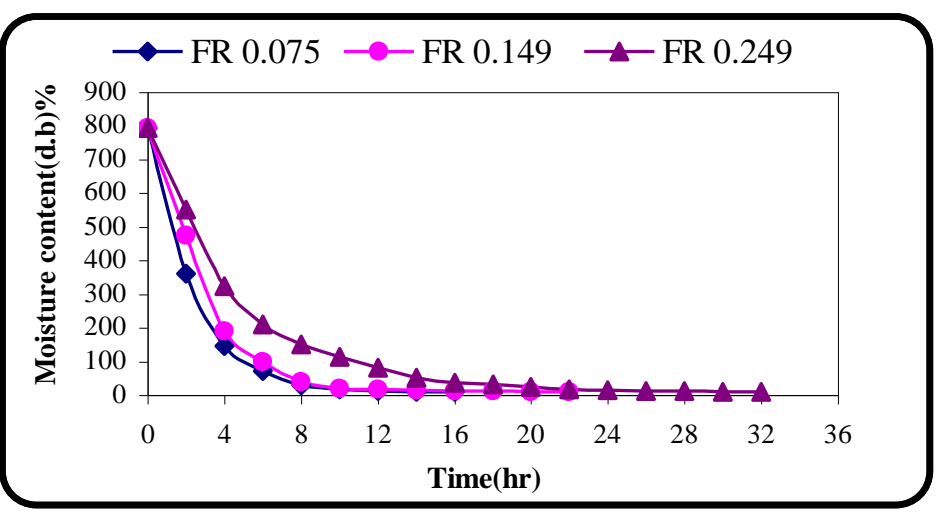

Fig. (2): Solar drying curves for okra by forced convection direct solar driers.

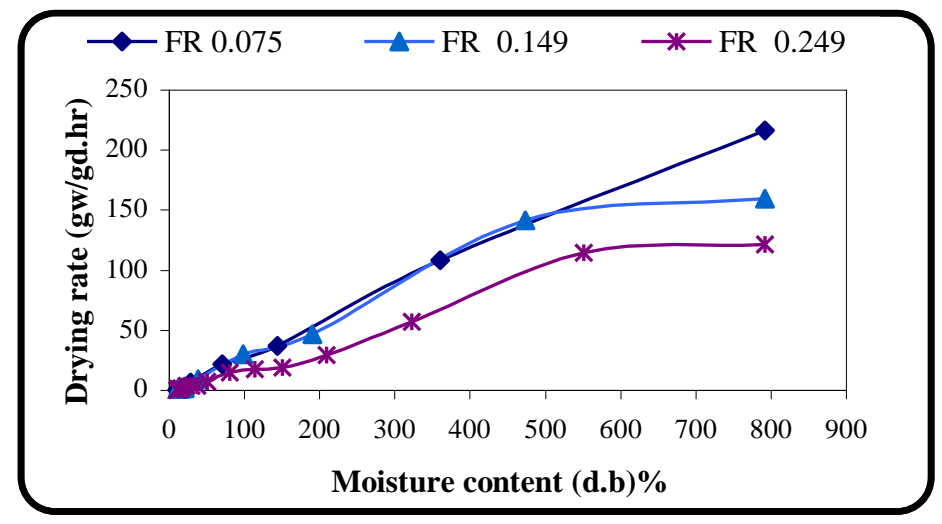

Fig. (3): Drying rate versus moisture content for okra by forced convection direct solar driers.

Meanwhile, the drying time to reach the final moisture content of 10.61 $\%$ (d.b) in the natural convection direct solar dryer was 24 hours. The drying time to reach the final moisture content of $10.82 \%$ in the forced convection indirect solar dryer with air flow rate of $0.075 \mathrm{~m}^{3} / \mathrm{sec}$ was 28 hours.

The maximum drying rate of pretreated okra occurred between 2 to 4 hours in the forced convection direct solar dryer with air flow rate of $0.075 \mathrm{~m}^{3} / \mathrm{sec}$. Meanwhile, it occurred between 2 to 6 hours in the natural convection direct solar dryer and occurred between 2 to 8 hours in the forced convection indirect solar dryer at air flow rate of $0.075 \mathrm{~m}^{3} / \mathrm{sec}$.

Fig.(5) shows the relationship between the moisture content \% (d.b) and the drying rate $(\mathrm{gw} / \mathrm{gdm} . \mathrm{hr}$ ) for okra dried by different solar driers. It 
revealed that short constant rate period which lasted down to a critical moisture content of about $31.53 \%$ (d.b) in the forced convection direct solar dryer with air flow rate of $0.075 \mathrm{~m}^{3} / \mathrm{sec}, 41.32 \%$ (d.b) in the natural convection direct solar dryer and $60.38 \%$ (d.b) in the forced convection indirect solar dryer with air flow rate of $0.075 \mathrm{~m}^{3} / \mathrm{sec}$, and exhibited approximately linear falling rate period.

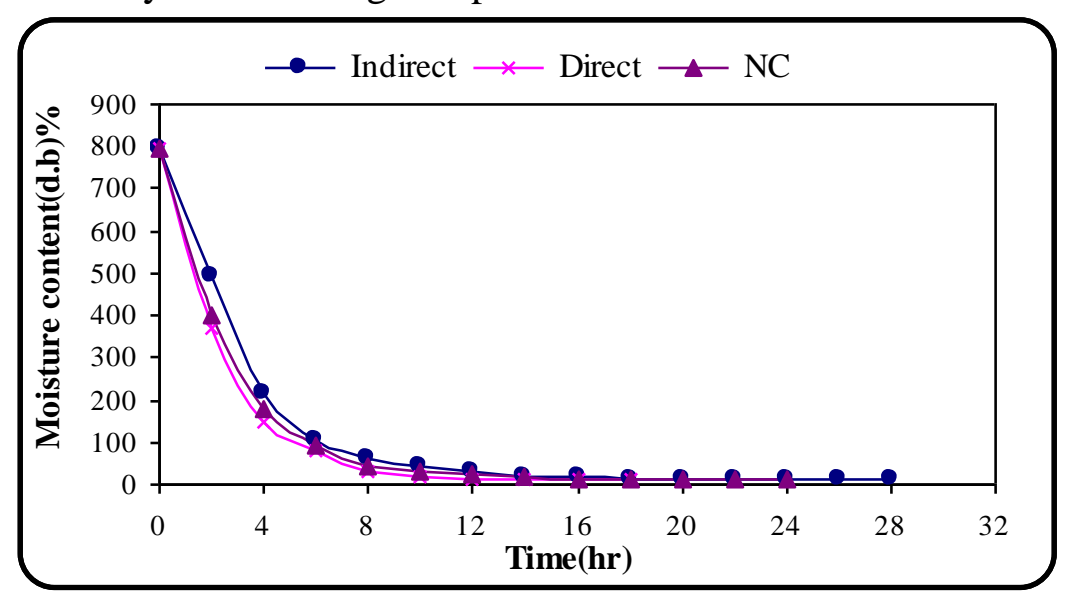

Fig. (4): Solar drying curves for okra using three different solar driers.

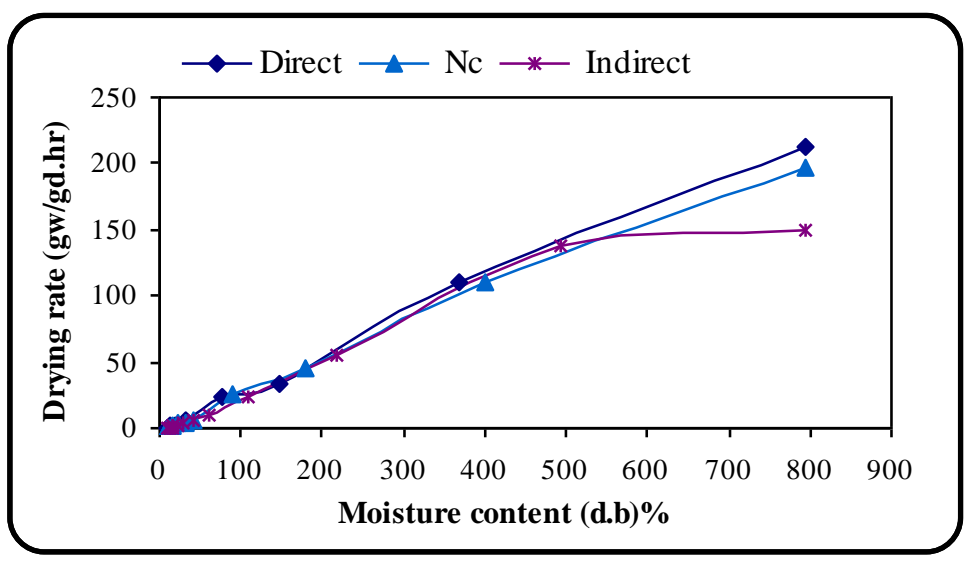

Fig. (5): Drying rate curves for okra using three different solar driers.

\section{Effect of drying methods on the drying efficiency of okra.}

Fig.(6) shows the relationship between solar time and the drying efficiency (\%) and the solar radiation for pretreated okra in the forced convection direct solar driers with different flow rates. The drying 
efficiency was relatively high at the beginning of daylight and reached the minimum afternoon, due to increase in solar radiation and decreased in drying rate.

The drying efficiencies of pretreated okra in the forced convection direct solar driers with air flow rate of $0.075 \mathrm{~m}^{3} / \mathrm{sec}$ was higher than that with air flow rates of $0.149 \mathrm{~m}^{3} / \mathrm{sec}$, and $0.249 \mathrm{~m}^{3} / \mathrm{sec}$, in the first 4 hours.

The maximum values occurred in the first day. The maximum values of drying efficiencies in the forced convection direct driers which loaded by pretreated okra with air flow rates of $0.075 \mathrm{~m}^{3} / \mathrm{sec}, 0.149 \mathrm{~m}^{3} / \mathrm{sec}$ and $0.249 \mathrm{~m}^{3} / \mathrm{sec}$ were $74.07,64.39,54.7 \%$, respectively.

Fig.(7) shows the relation between the drying efficiency, solar time and solar radiation ship for okra for the three different solar driers. The drying efficiency was relatively high at the beginning of daylight while reached the minimum afternoon, due to increase in solar radiation, and decreased in drying rate.

The drying efficiencies in the forced convection direct solar dryer with air flow rate of $0.075 \mathrm{~m}^{3} / \mathrm{sec}$ was higher than that in the natural convection direct solar dryer and the forced convection indirect solar dryer with air flow rate of $0.075 \mathrm{~m}^{3} / \mathrm{sec}$.

The maximum values of drying efficiencies in the forced convection direct solar dryer with air flow rate of $0.075 \mathrm{~m}^{3} / \mathrm{sec}$, in the natural convection direct solar dryer and in the forced convection indirect solar dryer with air flow rate of $0.075 \mathrm{~m}^{3} / \mathrm{sec}$ were $62.39,59.92,46.15 \%$, respectively.

\section{Mathematical models of okra drying.}

The values of the coefficient of determination, $\mathrm{R}^{2}$ and $\chi^{2}$ which describe the drying curves of pre treated okra in different solar driers were calculated.

The fitting model for describing the drying curves in the forced convection direct solar dryer were:- 


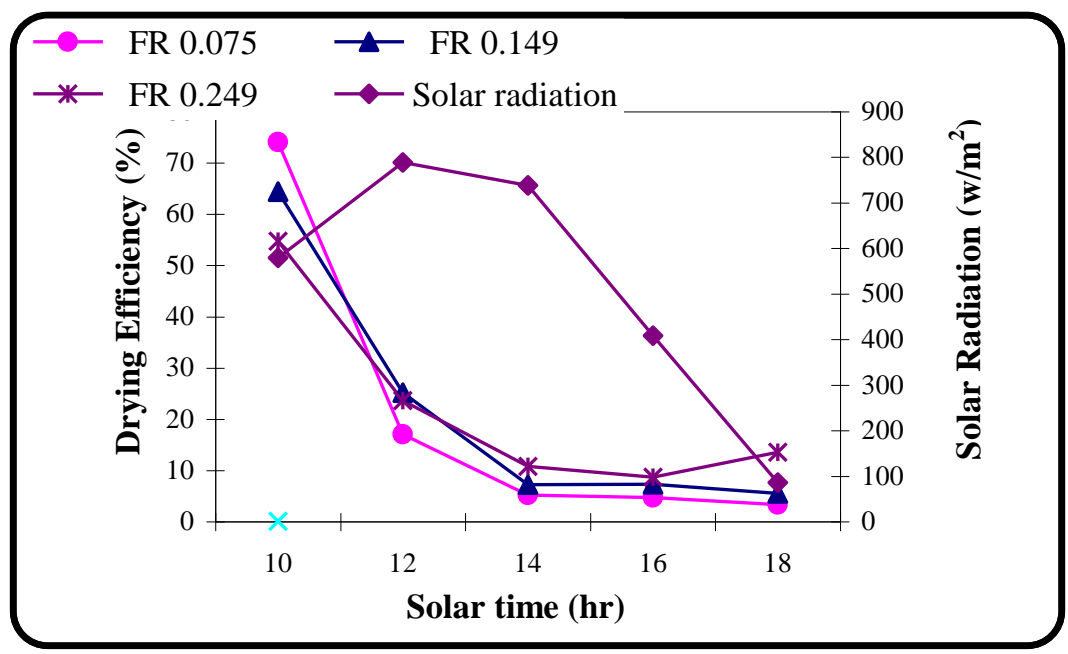

Fig. (6): Drying efficiency curves for okra dried by forced convection direct solar driers

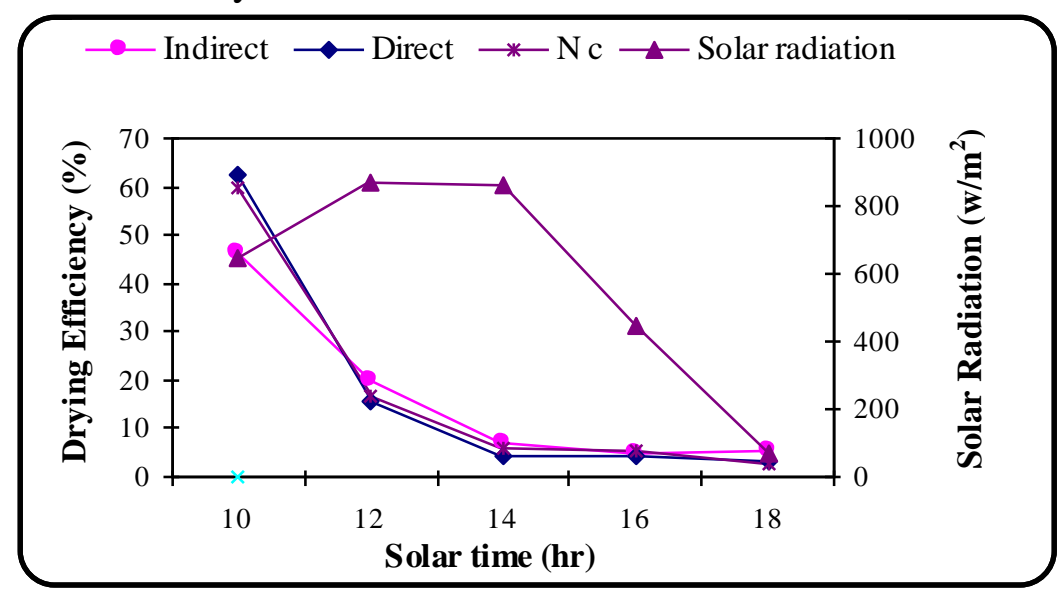

Fig.(7): Drying efficiency curves for pretreated okra using three different solar driers

At $0.075 \mathrm{~m}^{3} / \mathrm{sec}$ flow rate.

\section{Newton}

$$
\mathrm{MR}=\mathrm{e}^{(-\mathrm{k} . \mathrm{t})}
$$

And its constant was:

$$
\mathrm{k}=0.40524
$$

$$
\mathrm{R}^{2}=0.9994 \quad \chi^{2}=8.46186 \mathrm{E}-05
$$

At air flow rate of $0.149 \mathrm{~m}^{3} / \mathrm{sec}$ was:- 


\section{Approximation of diffusion}

And its constants were:

$$
M R=a e^{(-k . t)}+(1-a) e^{(-k . b . t)}
$$

$$
\begin{array}{ccc}
\mathrm{a}=-0.36439 & \mathrm{~b}=0.08482 & \mathrm{k}=4.90866 \\
\mathrm{R}^{2}=0.9992 & \chi^{2}=0.000184971
\end{array}
$$

At air flow rate of $0.249 \mathrm{~m}^{3} / \mathrm{sec}$ was:-

\section{Two term}

$$
\mathrm{MR}=\mathrm{a} \cdot \mathrm{e}^{(-\mathrm{k} 0 . \mathrm{t})} e^{\left(-k_{1} \cdot t\right)}+\mathrm{b} \mathrm{e}^{(-\mathrm{k} 1 \mathrm{t})}
$$

And its constants were:

$$
\begin{array}{ll}
\mathrm{a}=0.96598 & \mathrm{k}_{0}=0.22568 \\
\mathrm{~b}=0.04566 & \mathrm{k}_{1}=0.04298 \\
\mathrm{R}^{2}=0.9977 & \chi^{2}=0.00021884
\end{array}
$$

The fitting model for describe the drying curves of treated okra in the natural convection direct solar dryer was:-

\section{Midilli-Kucuk}

$$
\mathrm{MR}=\mathrm{a} e^{\left(-k \cdot t^{n}\right)}+\mathrm{b} . \mathrm{t}
$$

And its constants were:

$$
\begin{array}{cc}
\mathrm{a}=1.00157 & \mathrm{k}=0.33753 \\
\mathrm{n}=1.07893 & \mathrm{~b}=0.00088 \\
\mathrm{R}^{2}=0.9986 & \chi^{2}=0.000153465
\end{array}
$$

The fitting model for describing the drying curves of treated okra in the forced convection indirect dryer at air flow rate of 0.075 $\mathrm{m}^{3}$ /sec was:-

\section{Midilli-Kucuk}

$$
\mathrm{MR}=\mathrm{a} e^{\left(-k \cdot t^{n}\right)}+\mathrm{b} . \mathrm{t}
$$

And its constants were:

$$
\begin{array}{ll}
\mathrm{a}=0.99920 & \mathrm{k}=0.32588 \\
\mathrm{n}=1.03101 & \mathrm{~b}=0.00065 \\
\mathrm{R}^{2}=0.9995 & \chi^{2}=5.07816 \mathrm{E}-05
\end{array}
$$

\section{Quality of dried okra.}

The quality of dried okra was measured by testing final moisture content, rehydration ratio, bulk density and color.

The final difference in moisture content of the dried okra was not significant for all drying systems. Average final moisture content for dried product was $7.8 \%$ (d.b.). It can be seen that, The indirect solar 
dryer produced dried product with the highest rehydration ratio (average, 1 : 3.6). In all cases dried materials did not rehydrate to their initial moisture content on reconstitution. The natural convection direct solar dryer gave the highest bulk density in comparison with indirect solar dryer with $0.075 \mathrm{~m}^{3} / \mathrm{s}$ flow rate, indicating a considerable amount of shrinkage. Color of dried okra improved so much by using indirect solar dryer with different flow rates where the drying chamber was covered by a black sheet

\section{CONCLUSION}

From the present study, the following conclusions can be drawn as:-

1- Using the indirect solar dryer for drying okra with air flow rate of $0.075 \mathrm{~m}^{3} / \mathrm{sec}$ gave the best results.

2-The drying rate vs. the moisture content showed that the drying rate fell off decreasingly, describing a gentle curve accordingly, as the moisture content decreased.

3- The drying rate as well as the drying time were variable according to the drying method and drying air properties.

4-The best fitting model for describing the drying curves of pretreated okra in the forced convection indirect dryer with air flow rate of 0.075 $\mathrm{m}^{3} / \mathrm{sec}$ was Midilli-Kucuk MR $=\mathrm{a} e^{\left(-k . t^{n}\right)}+\mathrm{b} . \mathrm{t}$

5- The drying efficiency was decreased as the moisture content of okra decreased.

\section{REFERENCES}

Adom, K. K.; V. P. Dzogbefia; and W. O. Ellis (1997) "Combined effect of drying time and slice thickness on the solar drying of okra". J. Sci. Food Agric. (73), 315-320.

Awady, M.N.; A.M. Moustafa; and M.A. Genaidy (1988) "A trial on solar energy drying for agricultural products with simple setup". Misr, J. Ag. Eng., 5(3):377-392.

Ebru, K. A.; B. Yasar; and Y. Cengiz (2003) "Thin layer drying of red pepper". J. of Food Eng., (59):99-104.

El-Shiatry, M.A.; J. Muller.; and W. Muhlbauer; (1992) "Drying of fruits and vegetables with solar energy in Egypt". Agricultural Mechanization in Asia, Africa and Latin America 22 (4): 61-64. Cited by El- Yateem, (1995). 
El-Yateem, S. M. E. (1995) "Studies on the drying of some vegetables and fruits". M.Sc Thesis, Food Technology, Dep., Faculty of Agriculture, El-Minufiya University.

FAO, (2003) "Fao Stat Database". Available from: <http:// faostat.fao.org>.

Ghanem, T. H. (2003) "Improving Thermal Efficiency of A Flat Plate Solar Collector Using Nontraditional Coating Under Quasisteady conditions". Misr J. Ag. Eng., 20 (2):498-514.

Ibrahim, D. (2005)"Drying characteristics and kinetics of okra", Journal of Food Engineering 69,(3) 275-279.

Lahsasni. S.; M. Kouhila; M. Mahrouz; A. Idlimam; and A. Jamali (2004) "Thin layer convective solar drying and mathematical modeling of prickly pear peel (Opuntia ficus indica)". Energy;29(2):211-24.

Midilli, A.; and H. Kucuk (2003) "Energy and exergy analyses of solar drying process of pistachio". Energy 28, 539-556.

Mohamed, L. A.; M. Kouhila; A. Jamali; S. Lahsasni; N. Kechaou; and M. Mahrouz (2005) "Single layer solar drying behavior of Citrus aurantium leaves under forced convection". Energy Conversion and Management, 46:1473-1483.

Saad, M. M.; S. S. Rezk; and M. N. Metweally (1992) "Using the solar energy in drying the agricultural products". El-Dar El-Dawlia for Pub. And Delivering, Cairo, Egypt, (In Arabic)

Steinfield, A.; and I. Segal (1986) "A simulation model for solar thin layer drying process". Drying Technology, 4: 535-542.

Togrul, T. I.; and D. Pehlivan (2002) "Mathematical modelling of solar drying of apricot in thin layers". J. of Food Eng; 55 (3):209-16.

Yaldiz , O.; C. Ertekin; and H. Ibrahim Uzun (2001) "Mathematical modeling of thin layer solar drying of sultana grapes". Energy 26: 457-465.

Yaldiz. O.; and C. Ertekin (2001) "Thin layer solar drying of some vegetables". Drying Technoly;(19) (3\&4):583-97. 


\title{
الملخص العربى
}

\section{خواص التجفيف لثمار الباميا بواسطة أنظمة التجفيف الشمسي المختلفة}

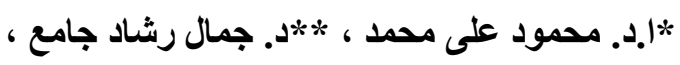

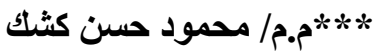

يعتبر التجفيف من الطرق الهامـة لحفظ الخضـر و الفاكهة و التجفيف الثمسي يعبر عن تقنيـة

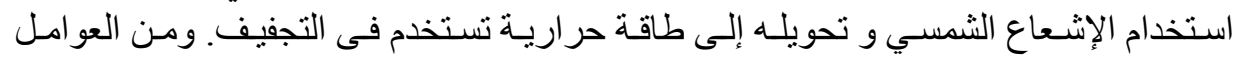

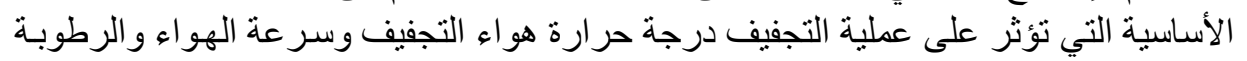

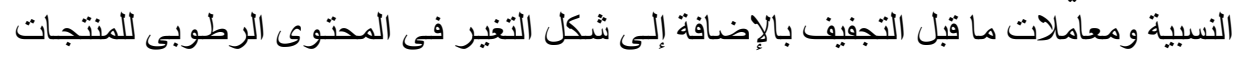

تحت التجفيف.

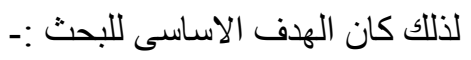

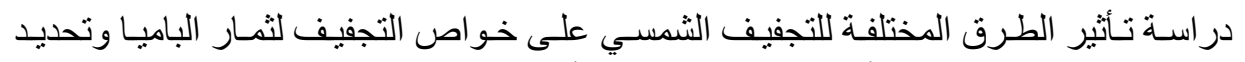
الظروف المثلي التي تعطى أفضل جودة للمنتج مع أعلى معدل تجفيف.

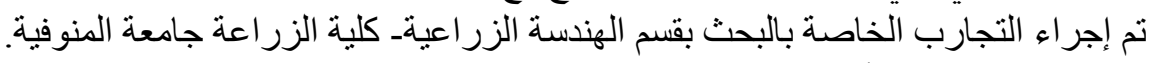
وقد شملت الدر اسة الأتي :-

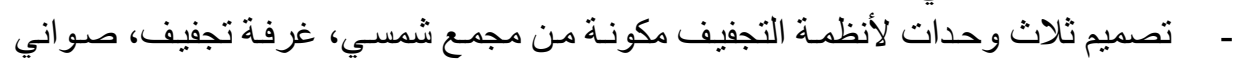

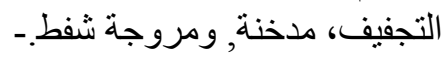

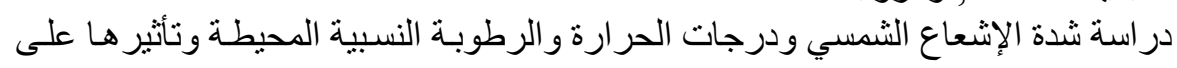

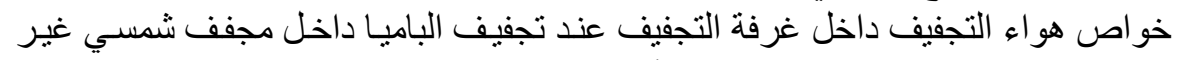

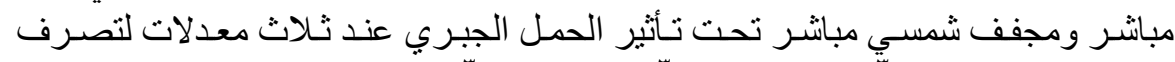

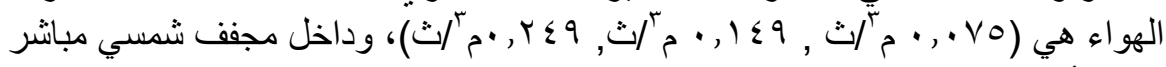

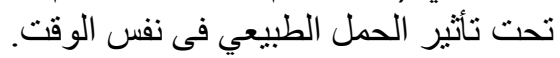

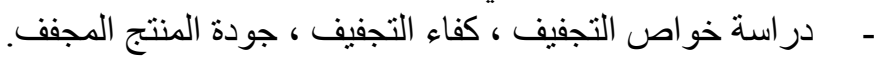

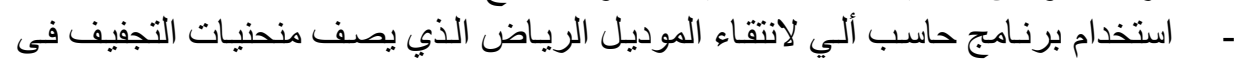
الحالات المختلفة.

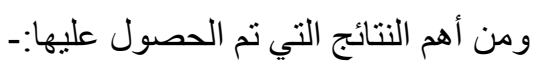

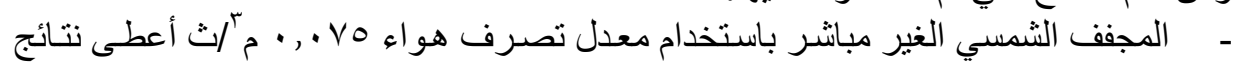
جيدة من حيث جودة المنتج ومعدل التجفيف.

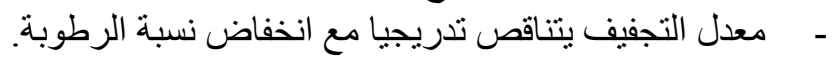

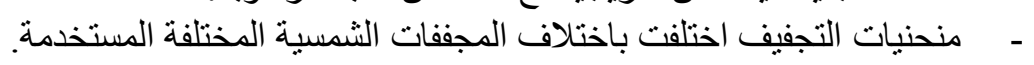

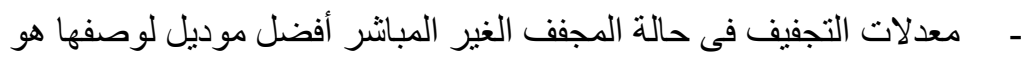

\section{Midilli- Kucuk \\ $\mathrm{MR}=\mathrm{a} e^{\left(-k . t^{n}\right)}+\mathrm{b} . \mathrm{t}$}

* أستاذ الهندسة الزر اعية - ورئيس قسم الهندسة الزر اعيةـ كلية الزر اعةـ جامعة المنوفية.

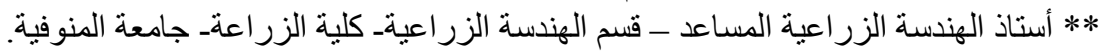

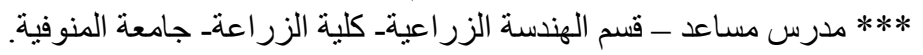

